\title{
A Survey of Biofuel Production potentials in Russia
}

\author{
Natalya Lykova, Royal Institute of Technology $(K T H)$, Department of Land and Water Resources Engineering, \\ Jan-Erik Gustafsson, Royal Institute of Technology $(K T H)$, Department of Land and Water Resources Engineering
}

\begin{abstract}
Due to the abundance of fossil fuel resources in Russia, the development of the renewable energy market there was delayed. Recent technological advancement has led to an increasing interest in biofuel production. The aim of research was to evaluate how biofuels are introduced into the current energy scheme of the country. The potential production of biofuels was estimated based on sustainable approaches which provide solution for carbon emission reduction and environmental benefits. Russia still requires biofuel policy to make biofuels compatible with traditional fossil fuels.
\end{abstract}

Keywords - biofuel, policy analysis, production potential, bioethanol, biodiesel, biobutanol, pellets.

\section{I.INTRODUCTION}

Since the beginning of the XXI century, biofuel production and consumption is constantly growing. The desire to reduce greenhouse gas emissions and to be less dependent on fossil fuel even further promotes biofuel development. Meanwhile, different biomaterials suitable for biofuel production make biofuel production attractive worldwide. However, Russia, as a main leader in fossil fuel export, had not been developing a bioenergy sector. Nonetheless, the availability of land and biomass resources creates favorable conditions for biofuel development.

The introduction of an innovative product is always a challenge for producers and the government. Biofuel is a new fuel for the Russian market and it is very important to properly present it to consumers. Currently, Russia has a relevant task to improve energy efficiency and find alternative sources of energy. Biofuel use is one possible way to reduce fossil fuel consumption in Russia. The government has already started to pay attention to biotechnology; however Russia still does not have a strong biofuel strategy. New biofuel facilities are established each year but the legal framework of the country creates barriers to local use.

\section{II.THEORETICAL FRAMEWORK}

Sustainable development means meeting the needs of the present without compromising the ability of future generations to meet their own needs [1]. Many scales were implied to study sustainable development including social, environmental and economic frames.

A visual representation of the sustainable development of the biofuel industry (Fig.1) shows the main aspects of the core concepts of sustainability within the framework of sustainable development. Three equally weighted categories of impact are usually considered: social, environmental, and economic [2]. There are issues that arise on the edges of each category, like social-environmental, environmental-economic and socialeconomic which, connected together, create the sustainable development of the industry. Regarding biofuel industry development, the main environmental-economic issues lay within the framework of energy efficiency, which requires biofuel production to become environmentally-friendly, in order to sustain the main idea of biofuel as an alternative fuel which can replace fossil fuel and be competitive in the market. Moreover, environmental-economic issues promote incentives to use natural resources involved in biofuel production in a rational way to produce waste and pollution as little as possible. Economic-social issues reflect problems regarding the fair trade of biofuel with a transparent production cycle and business ethics. Social-environmental problems refer to the concept of environmental justice and equal distribution of environmental wellness, as well as local and global natural resource stewardship. Social-environmental problems are connected to the biofuel production that should not compromise opportunities of people to have clean environment.

Proper consideration of all three aspects establishes sustainable biofuel production which will be beneficial to people and business and will be environmentally friendly for nature. A structuring of responsibilities for sustainable production can be based on sustainable development diagram (Fig. 1).

Based on the diagram, it is possible to conclude how sustainable approach may be implemented by government in cooperation with private companies (Fig. 2). 


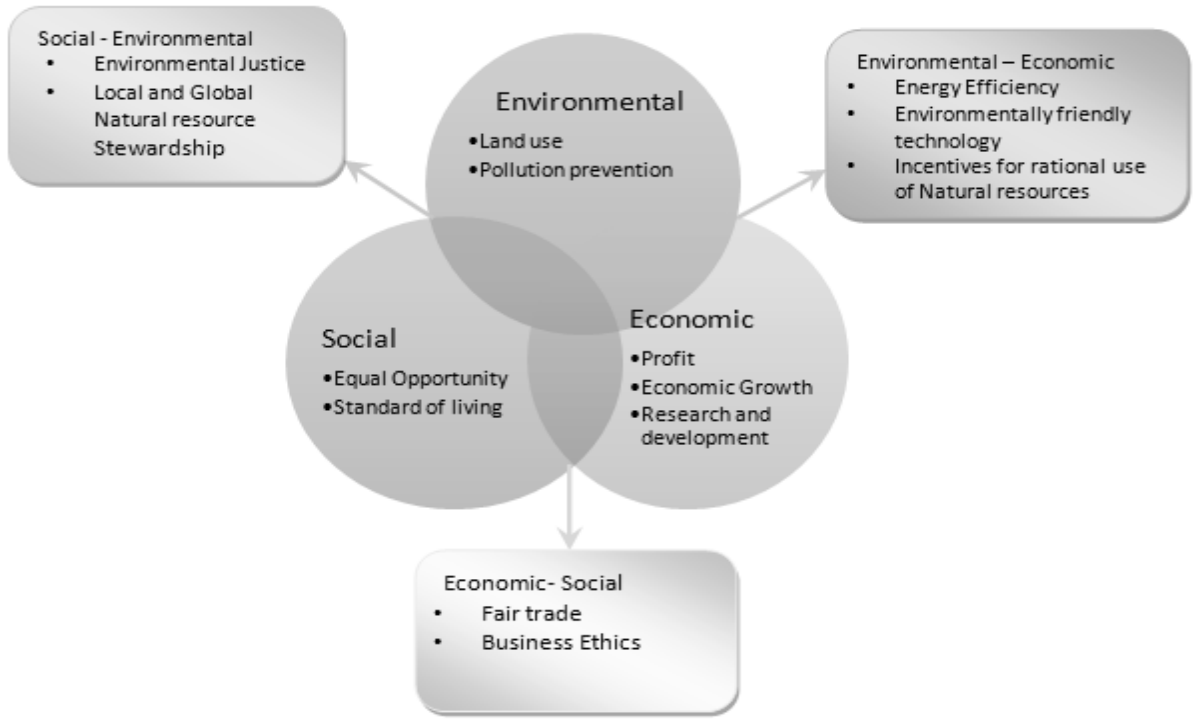

Fig. 1. Sustainable development diagram. Adopted from Rodriguez, Roman, Sturhahn, and Terry (2002).

In order to provide environmental-economic security, governmental institutions should provide conditions for businesses to develop and create a legislative framework for companies to work in. The figure below shows the key responsible governmental institutions in Russia. Social-

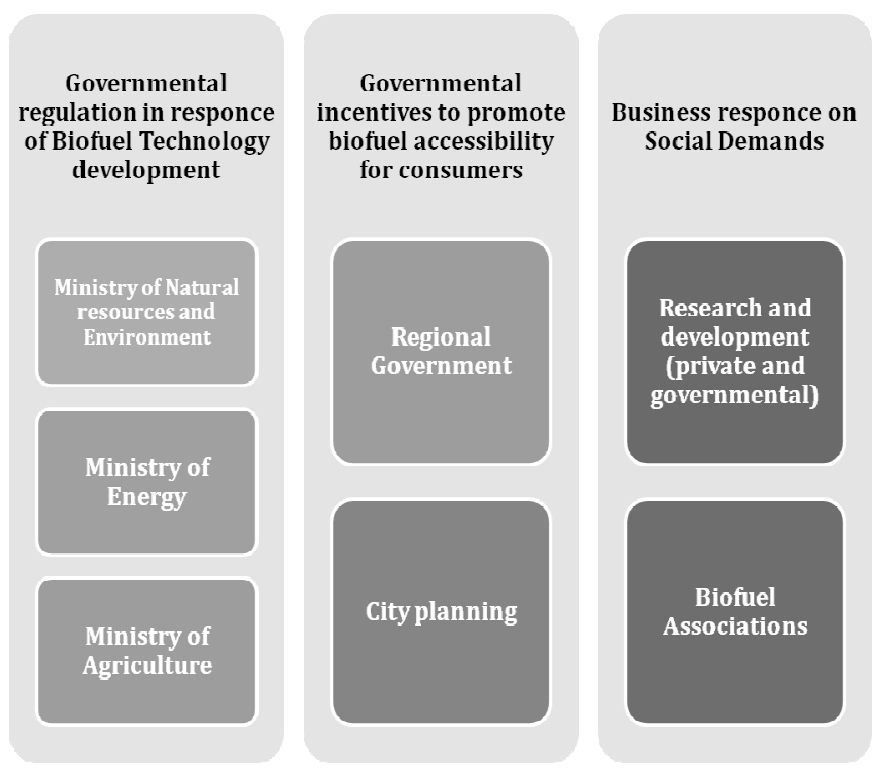

Fig. 2. Sustainable approach for the biofuel industry development.

economical demands are ensured by public-private partnerships, research and innovation programs, financed by the government or private investments and biofuel associations, to establish a proper response on the social demands for biofuels. Finally, social-environmental issues might be solved through the regional government which can respond to a social request faster and more efficiently.
The national government creates a basis in regard to an environmental strategy for the regional and municipal authorities to locally implement biofuel incentives and programs to respond to the social and economic demands.

\section{III.CURRENT SITUATION IN THE BIOFUEL MARKET IN RUSSIA}

Biofuels have gained a lot of attention in recent years, global Biofuel production increased from 209900 barrels per day in 2000 to 1,510300 barrels per day nowadays [3]. Modern technology makes it possible to produce biofuel in every part of the world, and Russia is no longer an exception. Naturally rich in fossil fuels, Russia is the second largest oil exporter and the first largest natural gas exporter in the world [4]; moreover Russia is also a large consumer. A strong and effective energy policy is a vital necessity for a compatible economy and the sustainable development of the country. A lot of attention is being paid recently to effective energy management in Russia. The new "Russia's Energy Strategy up until 2030" establishes the goal of an efficient, environmentally-friendly and financially-effective energy development strategy [5]. The reason behind this ambition is to renovate the out-of-date current energy system which is inefficient due to the low prices for energy resources, cold climate, energy intensive production, and outdated power technology equipment [6]. As a result, Russia needs 2,3 times more energy to produce one unit of GDP than the global average [6]. According to the "Russia's energy strategy", the country can save up to $360-400$ million tons of oil equivalent (toe), which is about $39-45 \%$ of the current annual energy consumption [5].

One of the ways to achieve effective energy management is the development of renewable energy. Attention to renewable energy sources remained very low until recent times due to the availability of traditional energy sources. Russia currently uses only $1 \%$ renewable energy from the total amount of its energy 
consumption [7]. The almost total abandonment of renewable energy has changed with the reformation of the energy policy. The target for 2020 is to increase the use of renewable energy sources up to $4,5 \%$ from the total amount of energy consumption [5]. It is impossible to switch completely to renewable energy in a short period of time, but now the priorities for energy development are nuclear, hydro power and other sources of renewable energy. It is expected to produce over 30 million $\mathrm{kWh}$ of renewable energy per year [5].

Besides having a sufficient amount of fossil fuel resources, Russia has a lot of land which is hard to reach due to its remote location (e.g. the Republic Yakutia) and therefore the use of traditional energy sources in these locations leads to significant energy losses. It is strategically reasonable to use available alternative energy sources, such as biofuels in these regions, as biofuel use can be a solution for the problem of fulfilling local energy demands. That is why local biofuel production is very important nowadays.

\section{IV.BIOFUEL INCENTIVES}

The government started to pay attention for the biotechnological industry rather recently, until 2008 there were no attempts to develop or systematize a governmental strategy regarding biotechnology. In Russia the development of biotechnology and particularly the biofuel industry has a bottom-up approach. The tendency of an increasing interest in biofuel on a global scale made producers in Russia begin biofuel research and development on a country level. The process of developing of legal framework was facilitated by the business biotechnological and biofuel associations. In January 2010, "A draft of the biotechnological industry development strategy until 2020" was presented in Russian parliamentary hearings which were the beginning of legal strategic policy planning for biotechnology. This was a joint effort of governmental and non-governmental organizations to establish a plan for the development of the biotechnological industry.

The aim of the Strategy is to implement industrial biotechnology to Russia using modern innovative approaches for the production of import-free domestic biotechnology products. It is a complex strategy that involves the innovative development of production, network formation, project development and financing mechanisms, including the development of a legal, economic and organizational framework, as well as the improvement of access to information and a system of training and education.

\section{A. Governmental incentives}

Biofuel production and technological development proceed while the legislation base is still at a stage of development. Federal laws "About the use of alternative types of motor fuel" and "About heat supply" presented to the state assembly in 2005, which would regulate stimulation measures for biofuel use in transportation and heat production on the governmental level are still at the stage of ratification. It is a complex program that involves all the types of renewable energy and promotion of biofuels use for the industry and private consumers. The laws are established to fulfill several functions [7]:

- Stimulation of renewable sources of energy use in heat and electricity production;

- Development of investment mechanisms;

- Governmental assistance to small-scale business;

- Establish equal competitive advantages in the market to biofuels;

- Legal promotion of bioenergy use;

- Raise awareness and facilitate information exchange and accessibility;

- Stimulation mechanisms for bioenergy consumers.

The Federal Program "Increase of energy consumption efficiency" was developed by the Ministry of Energy in order to sustain energy efficiency and promote the use of alternative energy in general and bioenergy in particular. One of the targets of the program is to create conditions for the innovation and use of alternative energy sources, biofuels for boilers and transport which will open new opportunities for energy savings [8].

\section{B. International Collaboration}

Russia actively participates in international cooperation in the development of innovative technologies. Cooperation and partnerships are established with many international programs and organizations such as the International Energy Agency, the International Council on Large Electric Systems, the International Partnership for Hydrogen and Fuel Cells in the Economy, the International Partnership for commercial use unconventional methane resources, the Global Bioenergy Partnership [7].

\section{Investment program}

In 2005 the Ministry of Economic Development and Trade, together with World Bank, created a "Russian Federation: Renewable Energy Project" subsidized by the Russian government and the Global Environmental Facility. The aim of the program is to solve the main barriers (financial, informational and institutional) for the development of renewable energy in Russia [9].

The program intends to provide technological assistance as well as investment support. By technological assistance it is assumed to support the development of legislation, federal programs for renewable energy and the creation of a modern database about technologies. The estimated total cost of the project is 80 million dollars and around $15 \%$ of the project will be invested in bioenergy [10]. As a result, the program expects to contribute to $\mathrm{CO}_{2}$ reduction, stimulate local energy generation in remote areas in Russia, and promote energy efficiency. The stimulation of industrial development by the project, improvement of infrastructure and the creation of jobs reinforces a positive social impact from the project.

\section{Local and private incentives}

The production of biofuel in Russia started by the private incentives in response to the growing European demand for biofuel. The first biofuel plans were small-scale productions 
on the experimental stage which created further development to local administration programs. Municipal and regional governments develop complex programs for bioenergy development, for instance the Republic of Chuvashia [11] and Republic of Tatarstan [12] adopted "A Strategy of Regional Bioenergy Development until 2020". According to the development strategy in Chuvashia, there is an intention to establish not only medical research centers for biotechnology development, plants for bio-additives production but also to construct several biofuel production centers intended to produce biodiesel, bioethanol and wooden pellets.

Targeted strategies for biofuel production and use were enacted on a regional level in order to promote biofuel use and production. For instance the Rostov region and Altay territories refine biodiesel production through a targeted regional program [13], the Leningrad regions promote biofuel use through a targeted program of wood production development in order to make wood production environmentally friendly by introducing a new production cycle which allows to produce pellets and bioethanol from waste wood [14].

Another type of biofuel incentive was adopted by Moscowcity government. This local incentive aims at introducing biofuels in city gasoline stations. The measure was created to reduce the level of harmful emissions from transport in the city. According to the city administration around 80 per cent of total emissions in the city come from transport [15]. The resolution provides a program for the promotion of biofuel use in public transport, as well as private. The department of transport and communication of Moscow foresaw an upgrade of buses in the public transportation system - several buses will use biofuels. As a pilot project attempt, a municipal public transportation company will be equipped with 300 busses working on dimethyl ether. The main challenge for the introduction of the new fuel to the general public is the creation of a convenient infrastructure for fuel supply, this obstacle is planned to be retrieved by the regulation to use at least one alternative fuel in the newly planned gasoline stations. Stimulation measures like tax exemption for private cars and compensation for vehicle upgrading were used for alternative fuel in Moscow [15].

Biofuel promotion measures are important to increase the public acceptance of biofuels. The Novgorod regional government is preparing a program for subsidizing pellet use in private housing. Locally-produced, pellet-fueled boilers bought for local heating supply will be subsidized up to $50 \%$ from the regional budget [16].

\section{E. Local educational partnership}

Educational collaboration is the main way to create the sustainable production of biofuel, to establish export cooperation and to create a basis for the exchange of experience. The Northwest federal district and the Swedish governmental program for Environmentally Adapted Energy System established cooperation and research for biofuel energy innovations which would result in the sustainable growth of biofuel production in Russia [17]. Sweden is a well- known leader for bioenergy use worldwide and educational and research cooperation contributes to the development of new technologies and mutual benefits.

The established project is aimed at creating mechanisms to create sustainable forestry and to improve forest management by a zero wastes plan, and to propose efficient technologies for the facilitation of waste wood use for pellet production [17].

\section{F. Private incentives}

The continuous rise of oil prices makes consumers search for cheaper alternatives. The fact that transport engines which work on biofuels are not yet widespread in Russia make the promotion of biofuel use difficult; biofuels are not properly introduced to private consumers that has made biofuel as motor fuel hardly accepted by the general public. Private companies are following the development of production and improvement of infrastructure facilities. Some companies started trials to check the compatibility and quality performance of biofuels.

During 2006-2007 the Russian Railways company organized trials for biodiesel from rapeseed. The performance of the locomotives was tested using 5, 10 and $20 \%$ blends of biodiesel [18]. The outcomes of testing proved that biodiesel has equal characteristics with fossil diesel and on some factors shows even better results. Russian Railways is ready to use biodiesel as a fuel for the trains. The interest in biofuels by the major railway company increased attention to biodiesel production in the region, and the oil manufacturer Masloproduct Company decided to build a biodiesel factory to supply Russian Railways with biodiesel [18]. Thus, the amount of biofuel produced correlates with the demand from consumers. The local consumption of biofuels might be increased by proper promotion measures through the mass media and governmental support.

Another incentive was made by a car manufacturing company AutoVaz to promote biobutanol use and announce research on butanol engines. In September 2008 the company organized a long-distance autocross using a biobutanol blend. Nevertheless, the large-scale car production which would be suitable to use biobutanol as a fuel needs, is not yet fully completed [19]. According to the interview with the presscenter, further work on engine modification will be initiated only after sufficient level of biobutanol production in Russia is reached and necessary infrastructure is developed for biofuel use such as gasoline stations network.

Hence, this lack of attention to biofuels represents a common attitude of car manufactories and demonstrates that the complex approach for production development is necessary. Private companies are ready to use biofuels but investment in the development of new technologies to use biofuels requires confidence that this technologies will be in demand.

\section{G. Tendencies on Biofuel market}

The survey of regional biofuel development shows a strong tendency for export oriented production, because of legislation barriers that prevent the local use of bioethanol. Moreover, 
only few regions (Novgorod and Leningrad regions) created local programs for biofuel use.

The examples of biofuel development in the regions provided above are not complete due to limited updated information and lack of information about small scale production. The majority of the companies producing bioethanol and biobutanol are large scale production companies with a big investment capital. Small scale production is considered unreliable and unprofitable due to export orientation of production and the low development of a local market. Moreover, the payback period is longer than in large scale production.

Pellet production is the most developed in Russia, because of the possibility for local use and export. Local pellet use is now in the development stage and many power plants still need upgrading but pellet producers are trying to introduce pellet fuel boilers in the local market.

Regarding the sources of biofuel, there are several possibilities for Russian producers. Russian ethanol producers are oriented on second generation biofuel from lignocelluloses biofuel from wood and agricultural waste to produce bioethanol and biobutanol. Wheat and corn are the most energy containing crops which can be grown in Russia for bioethanol production. And, finally rapeseed is the most suitable oil crop for the Russian climate for biodiesel production.

Rather mild climate in the central part of Russia and possibility to use all type of locally available biofuel crops made this region the most attractive region for biofuel production. Majority of biofuel plants are located in that region. Europe is the main biofuel consumer for Russian biofuel and close location is another factor for biofuel development in that region.

\section{V.PROBLEMS RELATED WITH BIOFUEL PRODUCTION AND USE}

An analysis of the potential problems for biofuel consumption and use presented below reflects all potential difficulties in biofuel production. Sustainable biofuel production is a goal of current global agenda. The framework (see Fig.1) of this research reflects all aspects of sustainable development such as social-environmental, environmentaleconomic and social-economic. However besides sustainability issues there are other problems related with biofuel production. Technological constraints can be factors which limit the production and use of biofuels and furthermore political obstacles can even prevent biofuel development in the region.

\section{A. Environmental-Economic}

Biofuel was introduced to the general public as an alternative to traditional fuel. Fossil fuel production is not environmentally friendly and is associated with risks for the environment. Biofuels in its turn was seen as environmentally friendly and a safe option to replace fossils.

Using biofuel production as a tool for waste management provides the economy with a suitable and efficient way to solve issues related to waste utilization and recycling. Pellets and ethanol production in Russia has been established to reuse wastes from forestry, the paper industry and agriculture. This is a sustainable approach, however nowadays there is little demand for biofuels, while there is a supply. Governmental incentives can change this situation and promote biofuel use in the local market in Russia. On the other hand the demand for fuel is much higher than the sustainable biofuel industry can produce, which means that producers, trying to satisfy the needs of the customers, might use other resources to comply with the demand. A well-balanced, resource efficient governmental strategy is required in order to regulate sustainable production.

Land use for growing crops and forests for biofuel purposes is under big debate nowadays. The location of a biofuel manufacturing plant depends on many factors, like accessibility, availability of labor and resources for production distance to consumer. Growth of demand for biofuels lead to increase of demand in resources, available land can be used for biofuel crops that causes land use change and as a result increase of total carbon emissions.

Another problem for biofuel production is environmental risks. Biofuel production based on agricultural products is highly dependent on natural factors, especially in Russia's changeable weather conditions. Recoupment time of a biofuel plant, according to the experts, is about two years [20], however this time can be increased sufficiently from environmental cause such as lean year (for example rapeseed) or emergency weather conditions. These factors can sufficiently decrease production performance, although risks are part of any production so companies should be aware of such risks and take appropriate measures to solve possible problems.

The fact that agricultural waste, such as wheat straws, was earlier used a lot in Russia as a natural fertilizer [21]. Now these wastes are used for biofuel production which can lead to impoverishment of lands. On the other hand, the production of fertilizers requires sufficient energy input and resources, therefore proper waste management and agricultural planning must ensure the security of sustainable agriculture and the preservation from environmental impacts.

Bioethanol production for local use is not profitable in Russia due to the federal law "About state regulation of production and marketing of ethyl alcohol, alcohol and alcohol containing products". As was mentioned before, the nominal price of 11 of ethanol including ethanol tax is about 0,8 Euros (30,5 rubles), while 1liter of gasoline is about 23 rubles $(0,6$ Euros) [22]. Therefore bioethanol production is now oriented towards the European market. Current biofuel production is mainly export oriented due to several reasons:

- Local legislation constraints

- Low development of infrastructure for biofuel use

- Low public awareness.

Local bioenergy programs propose bioenergy cluster development. With this approach it is possible to increase energy efficiency and reduce waste formation in the plant. Nevertheless energy efficiency in the factories is a subject of concern, renewable energy should be used for production, 
moreover up-to-date technology and innovative approaches can reduce energy consumption for biofuel production. In reality, when biofuel production of the local manufactures is not the main but one of the side products (for example in the regions in the Urals), it is unrealistic to upgrade the equipment frequently. In this case a closed cycle for biofuel production and local use can be a sustainable option to increase energy efficiency.

Local biofuel use can be developed through promotional measures, governmental assistance and legislation measures. On a company-level biofuel use as a part of the company's energy strategy improves environmental as well as economical performance and efficiency.

\section{B. Social-Environmental}

Biomass is a resource accessible to everyone; nevertheless the amount of biomass on the planet is not infinite. Sophisticated management of biofuel production is necessary to maintain the balance of biomass and ensure biodiversity.

The development of bioenergy industry moves agriculture towards using monoculture crops, which influence soil productivity. Specialization in one type of biofuel crop will lead to soil degradation; instead several types of crops can be used to avoid soil degradation and erosion. In the Krasnodar region, as the main food producer in Russia, where the field occupies a large territory, it is possible to produce rapeseed in a soil preserving way by changing the area for rapeseed planting. Other regions in Russia may also face this problem and should develop measures for soil preservation.

Biodiesel is considered to be biodegradable [23], the eventual toxic effects of ethanol are also considered as minimal to the environment [24]. Butanol is more toxic than ethanol but still biodegradable. Nevertheless, storage and transportation of biofuel has risks and requires proper assessment to minimize environmental and social risks. Any impact on the environment has harmful consequences not only to nature but also to people.

Land use change due to agricultural expansion leads to biodiversity loss, fragmentation and increased greenhouse gas emissions. One of the aims of sustainable bioenergy production is to use biofuel production as a tool for waste recycling; as a result it will decrease the need for new agricultural lands. The efficient use of available agricultural lands in Russia allows utilizing abandoned and empty farm lands. According to the Russian Minister of Agriculture (2009), around 30 million ha of agricultural lands are currently not in use in Russia. These lands can potentially be used for biofuel production. In this case, there is no need to compromise food to fuel and agricultural production remains at the same level.

In order to be fossil independent, biofuel production should be part of the renewable energy strategy, because only biofuels cannot solve the growing demand on fuel for cars, which constantly expects growth of the fuel supply. This fuel dependence subordinated the shapes of the cities and transportation habits. The replacement of fossil fuels by biofuels will not change this fact. The only solution is to decrease the consumption of fuel by managing public transportation, city planning and personal attitudes towards transportation needs.

It takes some time to restore biomass to produce the same amount of it. Growth of consumption will lead to growth in biofuel supply and as a result to biomass degradation caused by overproduction so it will be difficult to restore biomass.

Biofuel production should not compromise access to environmental benefits so that biofuel production will be distant from natural reserves and use environmentally friendly technology.

\section{Social-Economic}

Biofuel was introduced to the general public in Russia only recently and still bioethanol and biobutanol are not publicly accessible due to the unprofitability of local markets and even biodiesel is not yet very popular. Only pellets are publically available.

The delay of biofuel supply created by the legislation barrier can be used to establish an infrastructure to increase accessibility, because it always takes time to make innovative products available and convenient to use. This factor would increase the attractiveness of biofuels for consumers and they would more likely accept biofuels.

On the other hand not only biofuel producers but also car manufacturers and infrastructure developers are interested to find out whether existing users are enough to make the decision to switch from conventional fuels to biofuels before investing. Customers, in turn expect a variety of the flexiblefuel vehicles in the market and accessible filling stations for biofuels [25].

This fact creates a delay for biofuel introduction into the market on a large scale, but pilot projects in regional cities like Irkutsk and Krasnodar could increase public awareness and would make the process of biofuel integration into society milder.

Nowadays the majority of the biofuels produced in Russia is exported. The delay in the local market development provides the chance to avoid the problem of a lack of infrastructure and the establishment of a high level of demand.

Another major problem related with biofuel is food versus fuel dilemma. Russian biofuel producers see the current situation as a chance to develop the agricultural sector, enlarge the sown areas and attract investments [26]. However, if the management of the biofuel production will not be sustainable in terms of resources, for example if biofuel producers will switch to food crops from what is traditional for Russia (rapeseed), then this may lead to a growth in food prices. The company strategy should be transparent to the general public so that they can influence and reflect about the changes.

Regional programs for bioenergy development established by several regions promote competitiveness in the market and advance research and development in the industry, which should lead to better quality and services.

Social interests in biofuel production are very important to establish sustainable development, because society is the final consumer of the biofuels. 


\section{Political}

Besides intentions for sustainable development, the political strategy of the country is always a priority. Oil and gas export is one of the main concerns in the current political agenda. Fuel and energy complex provides over $50 \%$ income of the state budget, which is why biofuels has not got enough attention.

The number of vehicles and fuel consumption is rising while oil discoveries have been declining [27]. Meanwhile, the technological development of biofuel has reached a high level nationally and internationally and Russia is ready to provide alternatives to fossil fuel. Biofuel companies have appeared in the Russian market mainly due to the high demand in biofuels in the international market. Nowadays about $90 \%$ of produced pellets and $100 \%$ bioethanol is being exported [28].

Why is the local Russian market not developing? There are several legislation barriers that prevent biofuel market development. One of them already mentioned, the federal law "About state regulation of production and marketing of ethyl alcohol, alcohol and alcohol containing products", makes bioethanol production unprofitable in the local Russian market. Another one is the lack of promotion measures. The draft of the law "About the use of alternative motor fuels" has already been developed and presented at parliament hearings but was not been supported by the oil companies, although Gazprom (main gas company in Russia) is interested in this law but still does not actively lobby it, says RBC Daily. The following law is designed to make $50 \%$ tax exemption from the vehicle tax for alternative fuel cars [29]. The Government does not have a complex biofuel strategy which would allow performing complex policy and solving these issues.

Nevertheless standardization processes have been already started and the state standard "Unconventional technologies. Bio-waste energy. Concepts and definitions" has been commissioned [30]. Bioethanol producers try to lobby the amendment to the federal law "About state regulation of production and marketing of ethyl alcohol, alcohol and alcohol containing products" and include the notion of technical ethanol and exempt it from the alcohol taxation measure [28]. Until this measure is done, the bioethanol market in Russia has a very low chance for development.

A unified governmental policy is required to regulate the biofuel market and assist in biofuel promotion. Otherwise the current legislation framework will prevent the use of biofuel on a local level.

\section{E. Technological}

Resources for biofuel production can be found almost everywhere, however proper infrastructure and availability of land and water resources, and proper climate are requirements for the establishment of a successful production cycle.

Besides environmental constraints, there are some technological disadvantages of biofuel production as well as use. The main problem now in second generation bioethanol production is the conversion of cellulose and lignin in a way so that the waste products from the chemical process would be environmentally friendly. Moreover, as was mentioned before, biobutanol production requires technological enhancement to increase the yield. Both processes require being less energy demanding which, in turn; will make biofuels more economically attractive.

Regarding the use of bioethanol, there are concerns about increase of fuel consumption in the blends as well as $100 \%$ of ethanol fueled cars [31]. Older cars are not suitable to use even $10 \%$ blends [31]. This technological disadvantage makes bioethanol less attractive to the customers. One suggested solution is to further improvement of motor engines to increase fuel consumption efficiency. This strategy of performance improvement is being constantly used in traditional petroleum engines.

Another technological problem is vaporization. Alcohols have a low boiling point and high vapor pressure, during hot summer day it may cause vapor lock [32]. And otherwise, in winters fuel must be vaporized before burning in the engines but in the cold weather it may cause problems with engine starting [32]. Butanol has a lower vapor pressure and has better characteristics in engine performance.

Biodiesel use in Russia might be obstructed by the biodiesel performance in the cold weather. Biodiesel requires preheating before pumping when the outside temperature is low. Nevertheless use of the blend of $20 \%$ of biodiesel with $80 \%$ of traditional diesel illuminates this disadvantage. Consumers complain about the reduction of power of the engine and more frequent maintenance of cars.

Biodiesel transportation requires special management. Pipe transportation is complicated due to the increase of viscosity in low temperatures and has difficulties with storage in colder climates. For the Russian climate, this feature can significantly decrease compatibility of biodiesel. Furthermore, ethanol cannot be transported through oil-pipeline. These pipelines are not waterproof which means they will allow water to come inside. Ethanol is susceptible to water and will easily mix with it which will decrease the quality of ethanol and will be damaging for the vehicles that will use it [32]. Biodiesel and bioethanol can be transported by trucks and rail but this increases the cost. Biobutanol in turn is less susceptible to water and less corrosive than ethanol and thus it can be transported through the existing gasoline pipelines [33]. Moreover, alcohols can be corrosive to certain materials [32] and equipment that stores or uses alcohol as fuel must be checked regularly.

Despite some technological disadvantages, biofuels can still be used and produced in an efficient way and modern science can find solutions for the improvement of biofuel performance and compatibility. The next section evaluates the environmental-economic performance of biofuel in order to reveal positive and negative sides of biofuel production and use.

\section{ANALYSIS OF BIOFUEL POTENTIAL DEVELOPMENT IN RUSSIA}

The lack of institutional support, as was discussed earlier creates barriers for local market development. This causes financial obstacles due to a lack of investments in renewable 
energy. The low interest in biofuel keeps equipment prices high, due to low demand. The unstable economical situation prevents the development of long-term loans at affordable rates [9].

The development of the local biofuel market is currently not a priority for the government. Ethanol production will be cost efficient, as soon as bioethanol tax exemption is introduced to state legislation.

While political and legislation problems are still in the negotiation process on the state level, the development process of the regional biofuel industry moves forward. This fact seems to be controversial but local producers want to be ready to provide biofuel when all regulation issues will be solved.

Many regions are already working on bioenergy projects. Biodiesel production for the Russian local market is not yet cost efficient because European countries such as Germany, where biodiesel production is being subsidized by the government, are ready to buy rapeseed oil at even higher prices than biodiesel [28]. This is another limitation for biofuel production for local purposes.

Meanwhile, in the bio-clustered regions like Tatarstan, Irkutsk and Chuvashia, programs for biofuel promotion have already started by increasing awareness and access to information about the benefits and means of biofuel use.

Wood pellets are already available for the local private and industrial use. The energy performance of Russian heat and electricity producers is highly inefficient due to the use of outdated equipment. The introduction of biofuels to Russian industry will not only improve environmental performance, but also increase the energy efficiency of manufactures. Loss of electricity and heat in the stage of consumption and transportation in 2007 was 36,1 and 14,7 million of equivalent fuel, it is about $10 \%$ from total production [22].

Bioenergy as one of the instruments of the federal Program "Increase of energy consumption efficiency" can promote the use of new technologies or upgrading of existing equipment and improve energy efficiency on a regional as well as state level.

\section{A. Potential biofuels production capacity}

Bioenergy use can solve several problems in Russia, such as increase accessibility of energy and electricity for remote locations and low-populated areas. It might also be useful for heating of the country houses and villages which do not have access to central heating.

A Centralized heating and electricity system is the most common type of heating supply, which supply large areas with electricity and heat. Centralized heating systems make consumers more vulnerable; in case of emergency accidents many people will be cut off the heating supply. Biofuels like pellets allows decentralizing heating supply.

Scientists have difficulties to provide an accurate estimation of biofuel production. Available calculation data affirms the production capacity to be up to 117 million ton of bioethanol, 95 million ton of biobutanol per year [34].

However, this estimation does not provide information about the sustainability of production and makes it harder to understand if this amount of biofuel will contribute to the well being of the environment. Chasing the profit, producers sometimes does not pay attention to sustainable approaches. Especially if the waste wood industry and agriculture can be the source of biofuels, it can be a sustainable way to recycle the waste, which is very vital for Russia, because recycling is not developed in Russia on a large scale.

\section{B. Evaluation criteria}

The potential capacity of sustainable biofuel production has been calculated. Results are very approximate, because many assumptions were made during calculations and only two scenarios of biofuel development were taken into account. Nevertheless, the outcomes represent a tendency and show the approximate amount of biofuel which makes it possible to make a comparison with total consumption. From waste products it is possible to produce bioethanol, biobutanol, biogas and pellets. Beside the waste sources for biofuels, rapeseed was chosen as a source for biodiesel production due to the availability in current agricultural scheme of the country and the possibility to grow it in the majority of regions. Moreover rapseed will not compromise food needs of the Russian people as rapeseed oil is used only for technical purposes in Russia. Sunflower oil was not considered in this calculation due to its essential demand on a food market. Biogas production is hard to estimate based only on statistical data available for calculation and will not be presented in this research. Biobutanol production is still in the development stage and data regarding yield and energy balance is currently unavailable, thus biobutanol was eliminated from the calculation as well.

\section{Evaluation analysis and results}

Based on statistical data from the Federal statistical service about waste generation from the wood and paper industry and agricultural activity two scenarios of biofuel production have been proposed. According to Scenario A, all unutilized $^{l}$ wastes from the wood industry are used for pellet production, wastes from the paper industry and wheat straws as waste from agricultural industry are used for ethanol production and all rapeseed goes to biodiesel generation. In Scenario B all selected wastes (wood waste for pellet production, wheat residues and paper waste for bioethanol production) were used for biofuel production, biodiesel production remains constant, as agricultural changes has not been taken into account.

\footnotetext{
${ }^{1}$ By unutilized waste considered all the waste that had not been recycles or neutralized
} 
TABLE 1

POTENTIAL BIOFUELS PRODUCTION CAPACITY

\begin{tabular}{|l|l|l|l|l|l|}
\hline $\begin{array}{l}\text { Possible } \\
\text { biofuel } \\
\text { production, } \\
\text { year }\end{array}$ & $\begin{array}{l}\text { Pellets, } \\
\text { GWh }\end{array}$ & $\begin{array}{l}\text { Ethanol, } \\
\text { paper, } \\
\text { GWh }\end{array}$ & $\begin{array}{l}\text { Ethanol } \\
\text { wheat } \\
\text { straw, } \\
\text { GWh }\end{array}$ & $\begin{array}{l}\text { Diesel, } \\
\text { GWh }\end{array}$ & $\begin{array}{l}\text { TOTAL, } \\
\text { GWh }\end{array}$ \\
\hline Scenario A \\
\hline $\mathbf{2 0 0 5}$ & 3699,32 & 2297,83 & 1861,06 & 1088,41 & 8946,62 \\
\hline $\mathbf{2 0 0 6}$ & 4027,96 & 2068,05 & 2134,75 & 1868,92 & 10099,68 \\
\hline $\mathbf{2 0 0 7}$ & 4314,60 & 2757,39 & 4050,54 & 2259,17 & 13381,70 \\
\hline $\mathbf{2 0 0 8}$ & 3164,04 & 0 & 26875,9 & 2692,39 & 32732,33 \\
\hline Scenario B & 12513,6 & 15625,23 & 7827,401 & 1088,41 & 37054,64 \\
\hline $\mathbf{2 0 0 5}$ & 15357,6 & 14935,89 & 9469,513 & 1868,92 & 41631,92 \\
\hline $\mathbf{2 0 0 6}$ & 17064,0 & 12867,84 & 14560,06 & 2259,17 & 46751,07 \\
\hline $\mathbf{2 0 0 7}$ & 13651,2 & 15855,02 & 37166,47 & 2692,39 & 69365,08 \\
\hline $\mathbf{2 0 0 8}$ &
\end{tabular}

Results of estimation presented in the table above allow comparing possible sustainable biofuel production with total energy consumption in Russia. Of course real biofuel production capacity is higher than the estimated amount due to the fact that biofuels can be produced from other sources of waste, crops or biomass. However, the obtained results already confirm the idea that biofuels can generate a sufficient amount of energy. It is unrealistic to state that biofuels can replace all energy sources although it can have a sufficient share in the public energy consumption. Figure 3 demonstrates that biofuels can nearly cover energy needs of general public, reminding that there are other sources for biofuel production. It means that proper measures for biofuel energy development and promotion measures can sufficiently decrease fossil fuel dependency and in turn decrease carbon footprint.

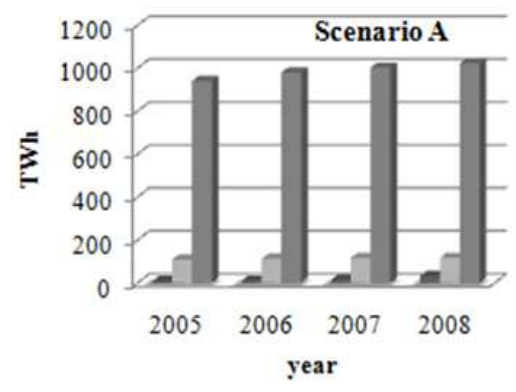

Energy from Biofuels

Energy for public needs

= Total energy consumption

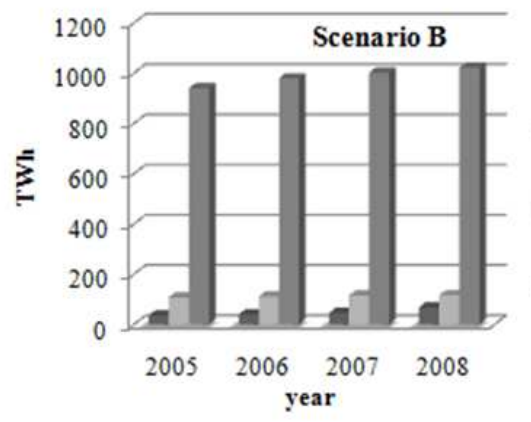

Energy from Biofuels

Energy for public needs

- Total energy consumption

Fig. 3. Biofuel share in energy balance for Scenario A and B.

\section{VII.RECOMMENDATIONS}

Biofuel was introduced to the Russian market recently and has not been favored yet. Political and legislative reasons prevent rapid growth of local markets, while the majority of biofuels produced in Russia goes to export, mainly to Europe [28]. A long-term practice of fossil fuel use, confidence and reliance of the customers to petroleum makes biofuel promotion difficult in Russia.

However global practice demonstrates significant changes in biofuel promotion. Sweden, the biggest player in the biofuel market, has a goal to be vehicle fossil fuel independent by 2030 [35]. Sweden was among the few countries that complied with the EU goal of replacing $2 \%$ of all petrol (diesel and gasoline) with biofuels by the end of 2005 [36]. This example demonstrates that proper management and governmental support can assist in developing the local market and sustainable production.

As was mentioned earlier, a planning strategy must compliment the bioenergy strategy. Biofuel incentive as an alternative fuel should go hand in hand with a strategy for the reduction of car use and the promotion of municipal transport. Biofuel itself cannot completely reduce greenhouse gas emissions. Only complex measures for fuel consumption reduction can lead to sustainable biofuel use.

Environmental advantages of all types of biofuels over fossil fuels are established, however as was mentioned biofuel production is not as cost efficient as fossil fuel production. European countries, such as Germany and Sweden actively subsidize biofuel production [28], while Russian incentives still lack governmental support.

Hence, based on the argument provided in the paper, to promote biofuel use and development of local application on $\boldsymbol{a}$ national level the following measures are necessary:

Apart from strategy for biotechnology development, develop a well-structured biofuel policy which foresees legal framework, financial mechanisms and promotional measures for biofuel production.

- Develop additional regional biofuel strategy and local policies based on the situation in the region.

- Develop complimentary action plans for popularizing biofuels and corresponding policies of waste management and agricultural changes.

- Create standardization and certification measures to establish competitiveness of biofuels in the market.

The biofuel strategy should define a role biofuel in energy schemes of the country, mention resources available for biofuel production, elaborate measures for financial support and stimulation of demand in biofuels. Financial support may have different ways to be established: direct grants from federal or regional budget for the regional production development, biofuel manufacturing projects or upgrading projects for biofuel use which are investment attractive and contributes for the local biofuel use. The feed-in tariff policy, which is common in Europe, supports renewable energy generation which provides guaranteed grid access and longterm contracts favorable purchase prices [37], can be a useful financial key factor for biofuel promotion. For instance, the 
industrial Yekaterinburg region, which has a developed wood industry and consumes about 5\% of total electricity consumption of Russia [22], has the capacity to develop a pellets and bioethanol industry. Upgrading district heat and power plants will allow increasing energy efficiency and decreasing air emissions in the region.

The main legal barrier for bioethanol access to the biofuel market is the federal law "About state regulation of production and marketing of ethyl alcohol, alcohol and alcohol containing products", which puts high taxes on bioethanol. It is required to create a tax exemption policy for bioethanol to reduce the price on it and make it accessible for the general public.

A regional bioenergy strategy, mentioned previously, has already started to function. A federal biofuel strategy should reflect the needs and create opportunities for research and development of regional programs.

Complementary programs for agricultural efficiency and land use, waste management and recycling policies can stimulate production and reduce bureaucratic barriers. An agricultural biofuel policy should be aimed at establishing lands available for biofuel production; preserving sustainable farming and put in use unutilized and empty lands.

A waste management policy is also a complex instrument and has difficulties for the implementation on a country level, especially if recycling programs are not applied on a large scale in Russia. However, waste management policies can be put into practice on local and regional scales. Such policies can increase the quantity of wastes suitable for biofuel production. The Swedish town Vesterås uses household wastes for biogas production for public transports, providing educational programs for the local population as stimulation for waste separation.

Biogas from sewage and waste program may be a suitable alternative on a local level. Eskilstuna (Sweden) commune is a good example of successful sewage management; the biogas program was implemented there for the local waste water treatment plant and uses obtained biogas as a fuel for the local busses. This program is difficult to apply without proper waste management; another problem is financial aspects for upgrading old sewage treatment plants. The federal program of reformation of housing and communal services started in 2003 can be another tool for regional and municipal governments to introduce new waste handling technologies [38]. Biogas from sewage is beneficial for the whole community and can reduce fossil fuel consumption on a local level.

Nevertheless, production of biofuel is only one side of the coin. Biofuels should have a demand among consumers (general public and private companies). State promotion should not be limited only to financial aid, it is important on the current stage of development to popularize biofuels. Information about biofuels is limited and requires improvement, information about the variety of regional programs; achievements in innovative approach should be accessible publicly. Information about advantages of biofuels is limited and compatibility as a fuel to engines is not spread among car owners. Biofuel is viewed to be a fuel for the future and an option for "not-today" discussed on various forums of car owners [39]. Biofuel producers should work on the popularization of biofuel use. A good practice was shown by the Corporation of biotechnology that organized promotion race from Irkutsk to Tolyatti on biofuel filled cars [40]. However, these measures seem to be insufficient and both governmental authorities and private companies should work on promotion measures.

State promotion measures can include a tax exemption policy for biofuel use. The main economical instruments used currently for fuel taxation mechanisms are the following [41]:

- Vehicle tax;

- Environmental classification of vehicles and tax differentiation;

- Excise duty on fuel;

- Taxation of company cars and free motor fuel.

The proposed exemption policy is to be applied on the environmental classification of vehicles and tax differentiation, which is part of the vehicle tax, and excise duty on fuel. Thus biofuel and biofuel cars will be promoted and will be profitable to buy and use.

Another financial measure can be "biofuel for heating tax exemption" as a public-private partnership between the government and biofuel consumers, organizations and private people that chose to produce heat and/or power in environmentally friendly way would have subsidies as promotion measures.

Besides financial assistance it is important to increase accessibility of fuels. A blending mandate, which already functioning in Europe [36], can be suitable for Russia as well, it will promote infrastructural development and improve environmental situation in general.

The success of policy implementation is defined by the level of commitment and willingness to make changes. Despite political and economical instability and the apparent fossil privileges that Russia has, there is room for alternative sources of energy. It is time to diversify the energy balance and accept environmentally friendly renewable technologies. The Minister of Energy of the Russian Federation announced recently that in five years Russia will start using biofuels. Only a couple of years ago Russia was an outsider in the global biofuel scheme, now the interest to biofuels has grown significantly therefore policy measures and governmental support should assist further developments.

\section{REFERENCES}

1. United Nations, 1987. Report of the World Commission on Environment and Development. United Nations.

2. Rodriguez S. I., Roman M. S., Sturhahn S. C. and Terry E. H. 2002. Sustainability Assessment and Reporting for the University of Michigan's Ann Arbor Campus. Ann Arbor: Center for Sustainable Systems University of Michigan.

3. US Energy information and administartion, International Energy Statistics. US Energy information and administartion. [Online]. Available at: http://tonto.eia.doe.gov/cfapps/ipdbproject/iedindex 3.cfm?tid=79\&pid=79\&aid=1\&cid=ww,\&syid=2000\&eyid=2008\&unit= TBPD [Assessed March 1, 2010].

4. OECD, 2009. Key World Energy Statistics 2009. OECD

5. Energy Strategy Institute, 2009. Energy strategy of Russia till 2030. [Online] Availiable at: http://www.energystrategy.ru/projects/es2030.htm [Assessed April 3, 2010] 
6. Kulagin V., 2008. Energy efficiency and development of renewables:Russia's approach. Russian analytical digest. Vol.46 , 2-8.

7. Ministry of Energy of Russia. (2008). Potentials of renewable energy sources. Ministry of Energy of Russia. [Online]. Available at: http://minenergo.gov.ru/activity/vie/ [Assessed Fabruary 2, 2010].

8. Gordukalov A. A. (2007). Prospects for energy balance in Russia:opportunities for optimization. Expert RA. [Online]. Available at: www.raexpert.ru/conference/2007/expert400/present/gordukalov.ppt [Assessed March 27, 2010].

9. Ministry of Economical Development and Trade, 2005. Russian Program of renewable energy sources development. Energo-inform. [Online]. Available at: http://www.energoinform.org/ normatives/ renewablere sourcesproject.aspx [Assessed February 1, 2010].

10. Global Environmental Fund. 2009. Global Environment Facility. Global Environmental Fund. [Online]. Available at: http://www.thegef.org/gef/node/1911 [Accessed February 1, 2010].

11. Voloshin Y. P. 2007. Russian Society of Biotechnologist. Rgional Programs and projects. Available at: www.biorosinfo.ru /regions/programma-chuvash.ppt [Accessed March 29, 2010].

12. TatNefteHimInvest-Holging. 2009. Biotechnology development is Republic of Tatarstan. Russian Society of Biotechnologist.[Online]. Available at: www.biorosinfo.ru/kalendar\%2520meropriyatiy/Parla ment Slushania 2009/Presentation Jarullin.pdf [Accessed April 19, 2010].

13. Administration of Rostov region, 2008. Administration of Rostov region: Target Regional program. Administration of Rostov region. [Online]. Available at: http://www.donland.ru/content/info.asp?partId=7 \&infoId=17636\&topicInfoId=17636 [Assessed April 5, 2010].

14. Leningrad region government, 2003. Decision of the Government of Leningrad region from 24.07.2003 N 154. [Online]. Available at: http://news-petersburg.com/docp/legal-xe/law-wiuwyy.htm [Accessed March 15, 2010].

15. Moscow City Government, 2007 b. Energy efficiency targeted program for 2009-2013 with perspective till 2020. Moscow City Government. [Online]. Available at: http://www.mos.ru/wps/portal/!ut/p/c1/jY 7LCsIwFEQ 6d48TO1SadJUJD4w2mRTgpRS6cOFCP696c6N1ZnlMH MGPEQP4dk24dGOQ-igBC8qqaQ6JJoiLiRDalK e2dRQ5CzmT1R mR63iBSFLIQ1Sofl6ey4wz9g bfyiFf5oX6a38 Qpn9k3euxrcOCTD07c nzinPd8IgkcE19VNuL7g3tsSb9y-AQ-mruA!/dl2/d1/L3dJVkkvd0xNQ [Assessed April 10, 2010].

16. Usmanova E, 2009. Novgorod region turns their boiler to pellets. Science and Technology RF. [Online]. Available at: http://www.strf.ru/science.aspx?CatalogId=364\&d_no=19172 [Assessed April 18].

17. Holodkov T. E, 2007. Swedish-Russian cooperation on Bioenergy development. Wood industries conferention of North West of Russia. [Online]. Available at: www.wicnwr.ru/news/Te_Holodkov.doc [Assessed March 26, 2010].

18. Russian Railways, (2008). Russian Railways tried biediesel in Voronezh Russian Railways. [Online]. Available at: http://press.rzd.ru/ isvp/public/press?STRUCTURE_ID=2\&layer_id=463\&id=209242

[Assessed March 30, 2010].

19. AutoVaz, 2010. Discussion on biofuels. [Letter] (Personal communication, February 16, 2010).

20. RosBusinessConsulting, 2008. Biofuel Production in Russia is being discussed. RosBusinessConsulting. [Online]. Available at: http://marketing.rbc.ru/news_research/25/06/2008/562949953429346.sht ml [Assessed May 17, 2010]

21. Zaichenko V., 2007. Round-table discussion "Complex use of waste and recycling in Russian Federation". Science and Technology Russian Federation. [Online]. Available at: http://www.strf.ru/science.aspx?CatalogId=222\&d_no=13357 [Assessed May 17, 2010].

22. Federal State Statistics Service, 2010. Federal State Statistics Service : http://www.gks.ru/ [Assessed May 3, 2010].

23. Peterson C. L., and Möller G., 2004. Biodegradability, BOD5, COD and Toxicity of Biodiesel Fuels. University of Odaho. [Online]. Available at: www.uiweb.uidaho.edu/bioenergy/BiodieselEd/publ ication/04.pdf [Assessed May 15, 2010]

24. State energy conservation office, 2006. Ethanol. State energy conservation office,Texas, USA. [Online]. Available at: http://www.seco.cpa.state.tx.us/re_ethanol.htm [Asseesed May 15, 2010].

25. Stockholm Environment Institute., 2007. Roles, potentials and challenges for biofuel end-users. Stockholm. Biofuel cities, quaterly. Vol. 2. [Online]. Available at: http://www.seit.ee/failid/446.pdf [Assessed May 17, 2010].
26. Chernobylets A., 2007. High-octane brew. Group of Companies "Titan". [Online]. Available at: http://www.titan-omsk.ru/Presscentr/Publikacii.html?\&nid=189 [Assessed May 15, 2010].

27. Campbell C., 2009. Oil Production is Reaching its Limit: The Basics of What This Means. [Online]. Available at: http://www.theoildrum.com/node/5969 [Assessed May 15, 2010].

28. Expert journal "Expert Economy", 2007. Half of gasoline in US has already ethanol additionl, while biofuel market in Russia do not exist. Expert journal "Expert Economy". [Online]. Available at: http://www.opec.ru/1103248.html [Assessed March 10, 2010].

29. Nazarova Y., 2010. Gas with a discount. RBC Daily. [Online]. Available at: http://www.rbcdaily.ru/2010/02/02/tek/456087 [Assessed April 10, 2010].

30. Federal agency for technical regulation and metrology, 2009. GOST P 52808-2007 Untraditional technologies. Energetics of biowastes. Terms and definitions. Federal agency for technical regulation and metrology [Online]. Available at: http://protect.gost.ru/document.aspx?control $=7 \&$ baseC $=6 \&$ page $=0 \&$ month $=10 \&$ year $=2008 \&$ search $=\& i d=173852$ [Assessed May 5, 2010]

31. Paul L., 2010. Bioethanol - the advantages and disadvantages. The green car [Online]. Available at: http://www.thegreencarwebsite.co.uk/ blog/index.php/bioethanol-the-advantages-and-disadvantages/ [Assessed May 15, 2010].

32. Smith J. L., and Workman J. P., 2004. Alcohol for Motor Fuels. Colorado State University, USA. [Online]. Available at: http://www.ext.colostate.edu/PUBS/FARMMGT/05010.html [Assessed May 10, 2010].

33. DuPont and BP, 2008. Biobutanol fact sheet. DuPont. [Online]. Available at: http://www2.dupont.com/Production_Agriculture/en_US /assets/downloads/pdfs/BP_DuPont_Fact_Sheet_Biobutanol.pdf [Assessed May 10, 2010].

34. Dracheva L., 2008. How to increase production and use of biofuels in Russia. Agricultural scientific journal "Agrarnyi expert".[Online]. Available at: http://agropressa.ru/prnwin.php?s=0\&na=544 [Assessed April 25, 2010].

35. Swedish EPA, 2009. Sweden's climate policy. Swedish EPA. [Online]. Available at: http://www.naturvardsverket.se/en/In-English/Menu/ Climate-change/Climate-policy/Swedens-climate-policy/ [Assessed May 18, 2010].

36. USDA Foreign Agricultural services, 2008. Sweden Biofuels Annual Report. GAIN Report, Global Agriculture Information Network. [Online]. Available at: http://www.fas.usda.gov/gainfiles/200807/ 146295116.pdf [Assessed May 1, 2010].

37. NREL, 2009, Technical Report NREL/TP-6A2-45549: Feed-in Tariff Policy:Design, Implementation, and RPS Policy Interactions. USA National Renewable Energy Laboratory [Online]. Available at: www.nrel.gov/docs/fy09osti/45549.pdf [Assessed April 11, 2010].

38. Poriadin A., 2008. Development of water disposal systems in Russia. Rosvodokanal. [Online]. Available at: http://www.rosvodokanal.ru /ru/branch/past/vodootvedenie/ [Assessed May 16, 2010].

39. Club Nissan forum, 2010. Biofuel vs. fossil diesel. Club Nissan web site. [Online]. Available at: http://www.club-nissan.ru/forums/ showthread.php? $\mathrm{t}=46166 \&$ page $=3$ [Assessed May 18, 2010].

40. RIA Novosti, 2008. The project of second generation biofuel will be presented in Irkutsk. AvtoVaz. [Online]. Available at: http://www.ladaauto.ru/cgi-bin/smi.pl?id=0\&id_article $=152873 \&$ prev $=14 \quad$ [Assessed March 30, 2010]

41. Shadrina T. , 2008. Fuel from sawdust. Rossiiskaya gazeta. [Online]. Available at: http://www.rostechn.ru/archive/2/detail.php?ID $=2774 \&$ phrase_id=53802 [Assessed April 16, 2010]

Natalya Lykova, MSc.

Royal Institute of Technology (KTH), School of Architecture and Built Environment

Address: Edinsvägen 22 B Läg 0226, Stockholm, Sweden, 13147 Nacka

Phone: +46765830285

E-mail: lykova@kth.se

Jan-Erik Gustafsson, Dr., Docent, Associate professor Department of Land and Water Resources Engineering Royal Institute of Technology (KTH)

Teknikringen 76, 1fl, SE-100 44 Stockholm, Sweden

Phone: +46 87907359

Fax.: +4684110775

e-mail: janerik@kth.se 
Natalja Likova, Jan-Erik Gustafsson. Apskats par biodegvielas ražošanas potenciālu Krievijā

Lai gan fosilā kurināmā pārpiln̄̄bas dēḷ Krievijā kavējās atjaunojamo enerǵijas avotu tirgus, nesenā tehnolog̣iju attīstība ir palielinājusi interesi par biodegvielas ražošanu, kamēr atbilstošas likumdošanas trūkums palēnina biodegvielas patēinu. Tirgus interese par biodegvielas izmantošanu ir iekustinājusi politikas veidošanas un likumdošanas pilnveides procesu, kas palielinās biodegvielas konkurētspēju. Šī pētījuma mērķis bija novērtēt, kā biodegviela ienāk pašreizējā enerǵijas sistēmā valstī. Situācijas analīze ir balstīta uz ilgtspējīgas attīstības teoriju. Biodegvielas ražošanai potenciāls ir aprēkināts, balstoties uz ilgtspējīgas lauksaimniecības un atkritumu apsaimniekošanas principiem, neapdraudot pārtikas ražošanu un meklējot dzīvotspējīgus risinājumus attiecībā uz oglekḷa emisiju samazināšanu un ieguvumiem videi. Piemēroti apstākḷi biodegvielas ražošanai un tehnoloǵiju pieejamība rada labus priekšnoteikumus ražošanas att̄̄stībai. Ilgtspējīga pieeja biodegvielas ražošanai garantē pietiekama daudzuma enerǵijas ražošanu, lai apmierinātu sabiedrības vajadzības. Valdības pasākumus biodegvielas veicināšanai papildina pašvaldību un privātā sektora rīcība, tomēr Krievijai ir nepieciešama labi strukturēta biodegvielas politika un veicināšanas mehānismi, lai panāktu biodegvielas saderību ar fosilo kurināmo un ieviestu šo jauno degvielu tirgū. Papildus nepieciešami pasākumi biodegvielas popularizēšanai, atbilstošas programmas atkritumu izmantošanai un lauksaimniecības reformēšanai, lai stimulētu biodegvielas ražošanas nozares attīstỉbu un veicinātu biodegvielas ienākšanu Krievijas enerǵêtikas nozarē

\section{Наталья Лыкова, Ян-Эрик Густафссон. Оценка производственного потенциала биотоплива в России}

Благодаря большим запасам ископаемых источников энергии в России, развитие биотопливной отрасли несколько запоздало. Однако, развитие новых технологий по производству биотоплива привлекло интерес к теме производства биотоплива. Отсутствие необходимой законодательной базы существенно замедлило темпы его производства. Принцип внедрения биотоплива носит характер «снизу-вверх», что способствовало процессу развития государственного регулирования в сфере биотоплива и увеличению конкурентоспособности биотоплив на рынке. Цель данного исследования - оценить ситуацию на рынке биотоплива и определить их место в энергетической схеме России. Анализ текущего положения дел был выполнен, основываясь на теории устойчивого развития. Более того, был произведен расчет потенциального количества биотоплива при условии применения принципов устойчивого развития в сельском хозяйстве и обращении с отходами, не подвергая риску производство продуктов питания и способствуя улучшению окружающей среды за счет снижения выбросов парниковых газов. Подходящая среда для производства биотоплива и наличие необходимых технологий создали благоприятные условия для производства биотоплива в России. Предложенный в работе метод производства биотоплива с точки зрения устойчивого развития обеспечивает количество энергии, которое способно удовлетворить потребности населения в энергии. Инициативы правительства дополняются местными и частными предложениями, но, тем не менее, России необходима целенаправленная программа по развитию биотоплива и механизмы поддержки для обеспечения конкурентоспособности с традиционными источниками энергии и внедрения новых видов топлива на рынок. Необходимы также дополнительные меры по популяризации биотоплива, соответствующие программы по утилизации отходов и реформирование сельского хозяйства, что поддержит развитие биотопливной отрасли и поможет внедрению биотоплив в энергетику России. 